\title{
PERAN ORGANIZATIONAL CITIZENSHIP BEHAVIOR PADA PENGARUH BUDAYA ORGANISASI DAN KOMITMEN ORGANISASI TERHADAP KINERJA KARYAWAN SKK MIGAS
}

\author{
Evi Marlina*, Niki Wulandari, Wira Ramashar \\ Fakultas Ekonomi dan Bisnis, Universitas Muhammadiyah Riau., Pekanbaru, Indonesia \\ *Email: evimarlina@umri.ac.id
}

\section{A R T I C L E I N F O}

Article History:

Received: 29 August 2020

Accepted: 01 October 2020

Available online: 29 October 2020

Keywords:

Budaya Organisasi,

Komitmen Organisasi,

Organizational Citizenship,

Kinerja Karyawan.

\begin{abstract}
A B S T R A C T
Kinerja karyawan merupakan hal yang sangat berperan menjaga sustainability organisasi. Kinerja karyawan dapat meningkatkan efesiensi dan efektifitas organisasi agar unggul dalam persaingan. Studi ini bertujuan untuk menguji pengaruh langsung budaya organisasi dan komitmen organisasi terhadap kinerja karyawan. Selain itu, studi ini juga ingin mengetahui efek moderasi organizational citizenship behavior dalam hubungan budaya organisasi dan komitmen organisasi terhadap kinerja karyawan. Penelitian ini menggunakan metode kuantitatif dengan pendekatan survey yaitu menyebarkan kuisioner pada tenaga alih daya pada SKK Migas perwakilan wilayah Sumbagut. Analisis data menggunakan regresi linear berganda dengan bantuan program aplikasi SPSS (statistic package for social science). Hasil penelitian menunjukkan bahwa budaya organisasi dan komitmen organisasi berpengaruh terhadap kinerja karyawan. Namun, penelitian ini tidak menemukan adanya efek moderasi organizational citizenship behavior dalam pengaruh budaya organisasi dan komimen organisasi terhadap kinerja karyawan.
\end{abstract}

\section{Pendahuluan}

Satuan Kerja Khusus Pelaksana Kegiatan Usaha Hulu Minyak dan Gas Bumi (SKK Migas) dibentuk berdasarkan Peraturan Presiden (Perpres) Nomor 9 Tahun 2013 yang bertujuan untuk pengelolaan bagian hulu minyak dan gas bumi minyak. Dalam menjalankan tugas pengelolaan minyak dan gas bumi SKK Migas berdasarkan Kontrak Kerja Sama. SKK Migas merupakan ujung tombak pemerintah dalam mengadaan minyak bumi dan gas alam tetapi beberapa tahun terakhir mengalami penurunan produktivitas migas.

Pada tabel 1 berikut ini disajikan tingkat produktifitas SKK Migas selama tiga tahun terkahir. Berdasarkan tabel tersebut menunjukkan bahwa adanya fluktuasi produktivitas, hal ini disebabkan selain rendahnya temuan cadangan minyak baru, juga diakibatkan rendahnya kualitas sumber daya manusia dalam penguasaaan tehnologi penemuan cadangan minyak baru (Dwi Sucipto, 2020). Dimana salah satu aplikasi teknologi yang akan dirancang Integrated Operation Center (IOC), menyajikan data migas secara nasional meliputi produksi, inventori, manajemen fasilitas, dan pengiriman bisa terpantau secara real time. Dengan sistem IOC ini akan memonitor $87 \%$ dari seluruh produksi migas di Indonesiadiharapkan selesai pada tahun 2022 . 
Tabel 1: Produktivitas SKK Migas 2016-2018

\begin{tabular}{ccccc}
$\begin{array}{c}\text { Jenis } \\
\text { Bahan } \\
\text { Tambang }\end{array}$ & $\begin{array}{c}\text { Satuan } \\
\text { unit }\end{array}$ & 2016 & 2017 & 2018 \\
\hline $\begin{array}{c}\text { Minyak } \\
\text { Bumi } \\
\text { Gas } \\
\text { Alam }\end{array}$ & Barel & 269.613 & 292.374 & 281.827 \\
MMSCF & 2.905 .465 & 2.781 .154 & 2.833 .784 \\
\hline
\end{tabular}

Sumber: Badan Pusat Statistik, 2020

Disamping itu tenaga kerja pada SKK Migas terdiri atas pegawai tetap, pegawai tidak tetap atau tenaga kerja waktu tertentu (TWKT), dan tenaga alih daya (TAD). Dimana masing-masing terdapat perbedaan dari segi tanggung jawab pekerjaan, gaji, tunjangan, dan lain sebagainya. Sehingga hal ini mengakibatkan pada kelompok tenaga alih daya mengalami penurunan kinerja di karenakan perbedaan benefit yang mereka terima lebih kecil dibandingkan dengan pegawai tetap atau pegawai tidak tetap.

Dalam konteks ini peneliti menduga budaya organisasi dan komitmen organsasi berpengaruh terhadap kinerja karyawan. Budaya organisasi merupakan suatu persepsi bersama yang dianut oleh semua anggota atau sistem makna bersama yang dihargai oleh organisasi. Di sisi lain, budaya organisasi memiliki dampak yang kuat pada perilaku karyawan, sehingga organisasi bisa berjalan secara efektif dan efisien.. Dengan menerapkan budaya organisasi didalam perusahaan maka akan membentuk karakter karyawan melalui kebiasaannya terhadap perusahaan sehingga karyawan memahami maksud dan tujuan perusahaan yang berdampak langsung terhadap kinerjanya (Marlina \& Zega, 2019). Hal ini sejalan dengan hasil penelitian Tumigolung et.al. (2019) dan Rosyidah et. al. (2019) menunjukkan hasil bahwa budaya organisasi berpengaruh terhadap kinerja karyawan. Sedangkan hasil studi Megantara et.al. (2019) dan Herdiany (2015) menyatakan bahwa budaya organisasional tidak berpengaruh terhadap kinerja karyawan.

Selanjutnya komitmen organisasi, merupakan dimensi perilaku penting yang dapat digunakan untuk menilai kecenderungan karyawan untuk bertahan sebagai anggota organisasi. Komitmen merupakan identifikasi dan keterkaitan seseorang yang relatif kuat terhadap organisasi. Komitmen organisasional yang tinggi memiliki perbedaan sikap dibanding yang berkomitmen rendah. Perilaku komitmen organisasional menghasilkan peforma kerja, rendahnya tingkat absen dan rendahnya tingkat keluar masuk (turnover) karyawan (Widodo et.al., 2019). Sehingga dengan adanya komitmen yang tinggi didalam diri karyawan, maka meningkatkan kesadaran bahwa apa yang dilakukan semata untuk perusahaan yang berdampak langsung terhadap kinerjanya. Hal ini sejalan dengan hasil penelitian Tumigolung et. al. (2019); Rosyidah et. al. (2019); Joko et. al. (2019); Widodo et. al. (2019) menunjukkan hasil bahwa komitmen organisasional berpengaruh terhadap kinerja karyawan. Sedangkan hasil studi Marsoit et. al. (2017) dan Akbar et. al. (2017) menunjukkan komitmen organisasional tidak berpengaruh terhadap kinerja karyawan.

Oleh karena ketidakkosistenan hasil penelitian sebelumnya, peneliti menduga ada varabel lain yang berperan dapat memperkuat dan memperlemah hubungan atara budaya organisasi dan komitmen organisasi dengan kinerja karyawan. Organizational citizenship behavior merupakan bentuk perilaku yang merupakan pilihan dan inisiatif individual, tidak berkaitan dengan sistem reward formal organisasi tetapi secara agregat meningkatkan efektivitas organisasi. Dimana perilaku organizational citizenship behavior tidak termasuk ke dalam persyaratan kerja atau deskripsi kerja karyawan sehingga jika tidak ditampilkan pun tidak diberikan sanksi oleh perusahaan. Dengan demikian, perilaku tersebut dapat memberikan hasil yang positif bagi perusahaan, baik untuk tujuan perusahaan itu sendiri maupun untuk kehidupan sosial dalam perusahaan tersebut yang berdampak langsung terhadap kinerja karyawan. Hal ini sejalan dengan hasil penelitian Halim dan Dewi (2018), Defrionaldo dan Rivai (2019), Aprianti dan Baihaki (2017), Widodo et. al. (2019), dan Kurniawan et. al. (2019) menunjukkan hasil bahwa organizational citizenship behavior berpengaruh terhadap kinerja karyawan.

Penelitian ini merupakan pengembangan dari penelitian Tumigolung et .al. (2019) dengan menambahkan organizational citizenship behavior (OCB) sebagai variabel moderasi. Tujuan penelitian ini untuk 
mengetahui organizational citizenship behavior memoderasi pengaruh budaya organisasi dan komitmen organisasiterhadap kinerja karyawan. Selanjutnya kontribusi penelitian secara teoritis pengayaan referensi teori pertukaran sosial dan secara praktis Agar SKK Migas Sumbagut lebih peduli terhadap karyawan khususnya tenaga alih daya.

\section{Tinjauan Pustaka dan Pengembangan Hipotesis}

2.1 Teori Pertukaran Sosial (Social Exchange Theory)

Menurut Fung et. al. (2012) menyatakan bahwa teori pertukaran sosial merupakan pandangan karyawan ketika mereka telah diperlakukan dengan baik oleh organisasi, mereka akan cenderung untuk bersikap dan berperilaku lebih produktif terhadap organisasi. Setiap individu selalu berusaha untuk membalas budi terhadap siapapun yang telah memberikannya keuntungan.Teori pertukaran sosial menjelaskan bagaimana menjaga keseimbangan pertukaran sosial antara karyawan dan organisasi. Ketika karyawan merasa puas dengan pekerjaannya, mereka akan membalasanya. Balasan dari karyawan tersebut termasuk perasaan yang menjadi bagian (sense of belonging) dari organisasi yang menyebabkan perilaku seperti organizational citizenship behavior (Mahardika dan Wibawa, 2019).

Secara umum, hubungan sosial terdiri dari orang-orang, perilaku kita dan orang lain telah melihat mempengaruhi satu sama lain dalam sebuah hubungan, yang ada unsur disiplin, pengorbanan dan keuntungan.Teori pertukaran sosial merupakan sebuah teori dalam ilmu sosial yang menyatakan bahwa ada unsur disiplin hubungan sosial, pengorbanan, mendapatkan dan saling mempengaruhi. Teori ini menjelaskan bagaimana manusia melihat hubungan kita dengan orang lain sesuai dengan asumsi bahwa manusia terhadap (Setiawan, 2019): (1) Keseimbangan antara apa yang diberikan kepada hubungan dan apa yang dikeluarkan dari hubungan itu; (2) Jenis koneksi yang dibuat; dan (3) Kesempatan untuk memiliki hubungan yang lebih baik dengan orang lain.

Proses pertukaran sosial ini juga telah diungkapkan oleh para ahli sosial klasik.
Seperti yang diungkapkan dalam teori ekonomi klasik abad ke-18 dan 19, para ahli ekonomi seperti Smith (1776) sudah menganalisis pasar ekonomi sebagai hasil dari kumpulan yang menyeluruh dari sejumlah transaksi ekonomi individual yang tidak dapat dilihat besarnya. Ia mengasumsikan bahwa transaksi-transaksi pertukuran akan terjadi hanya apabila kedua pihak dapat memperoleh keuntungan dari pertukaran tersebut, dan kesejahteraan masyarakat pada umumnya dapat dengan baik sekali dijamin apabila individu-individu dibiarkan untuk mengejar kepentingan pribadinya melalui pertukaranpertukaran yang dinegosiasikan secara pribadi (Setiawan, 2019).

\subsection{Pengaruh Budaya Organisasi Terhadap Kinerja Karyawan}

Perlunya budaya organisasi sebagai landasan norma-norma dan nilai-nilai untuk dianut dan diterapkan oleh karyawan dalam mewujudkan tujuan perusahaan.Karyawan yang bekerja berlandaskan budaya organisasi diharapakan mampu memberikan yang terbaik dan membawa pengaruh terhadap kepuasan kerja dari karyawan karena karyawan merasa nyaman di mana karyawan tersebut bekerja.Salah satu terpenuhinya kepuasan kerja karyawan tidak lepas dari adanya peranan dari budaya organisasi (Putra et. al., 2018). Budaya organisasi penting, karena merupakan kebiasaan-kebiasaan yang terjadi dalam hirarki organisasi yang mewakili norma-norma perilaku yang diikuti oleh paraanggota organisasi. Budaya yang produktif adalah budaya yang dapat menjadikan organisasi menjadi kuat dan tujuan perusahaan dapat terakomodasi (Rosyidah et. al., 2018). Sehingga karyawan yang mampu menyesuaiakan dengan budaya organisasi dimana karyawan tersebut bekerja akan membawa kinerja yang baik terhadap organisasi.

Menurut Robbins dan Judge (2017) budaya organisasi merupakan serangkaian kegiatan yang diterapkan oleh angota organisasi secara bersama yang menjadi pembeda antara suatu organisasi dengan organisasi lainnya. Dimana akan mempengaruhi cara seseorang dalam bertindak dan berpikir sehingga mejadi landasan penilaian baik dan buruknya tindakan karyawan. Dengan kata lain budaya organisasi 
merupakan suatu yang dipersepsikan karyawan dan kiat persepsi itu mewujudkan suatu pola keyakinan, nilai, dan ekspektasi (Claresta, 2019). Sehingga dapat disimpulkan bahwa semakin tinggi budaya organisasional yang dimiliki karyawan maka memberikan hasil kinerja karyawan yang baik dan positif didalam suatu organisasi.

Teori pertukaran sosial menurut Fung et. al. (2012) menjelaskan bagaimana menjaga keseimbangan pertukaran sosial antara karyawan dan organisasi.Organisasi memiliki budaya masing-masing yang diterapkannya sedangkan karyawan yang berada didalam organisasi tersebut harus menyesuaikannya. Karyawan yang mengikuti tata aturan dan budaya di tempat kerjanya menunjukkan adanya hubungan sosial di dalam diri karyawan yang mampu menciptakan hubungan baik antar sesama karyawan baik didalam pekerjaan maupun di luar pekerjaan. Sehingga budaya organisasi yang berjalan efektif mampu meningkatkan kinerja karyawan. Hasil penelitian Tumigolung et. al. (2019); Rosyidah et. al. (2019) menunjukkan bahwa budaya organisasional berpengaruh terhadap kinerja karyawan.

H1: Diduga budaya organisasi berpengaruh terhadap kinerja karyawan.

\subsection{Pengaruh Komitmen Organisasi Terhadap}

\section{Kinerja Karyawan}

Komitmen organisasi yaitu sikap yang dimiliki oleh para pegawai sehingga menjadi pendorong untuk memberikan hasil terbaik terhadap sesuatu tanggung jawab yang diberikan (Dewi dan Hasniaty, 2017). Maka dari itu komitmen organisasi yang dimiliki karywan akan dapat menahan dirinya untuk pindah kerja ke perusahaaan lainnya sehingga dapat mengurangi biaya turn over suatu perusahaan dan juga memaksimalkan pekerjaannya di satu perusahaan tersebut (Widodo et. al., 2019). Oleh karena itu harus menjadi perhatian utama untuk mengestimasikan komitmen anggota organisasi secara akurat dalam mengembangkan program-program sehingga kegiatan yang dilakukan dapat meningkatkan komitemn anggota organisasi tersebut. (Maghfironsyah dan Yuniawan, 2019). Jadi komitmen organisasi akan memberikan dampak secara nyata secara nyata kinerja sumber daya manusia yang dimiliki dan pada akhirnya berpengaruh terhadap kinerja suatu organisasi (Joko et. al., 2019). Dengan demikian, semakin tinggi komitmen karyawan kepada organisasi maka secara tidak langsung memiliki hubungan emosional antara karyawan dengan perusahaan.

Teori pertukaran sosial menurut Fung et. al. (2012) menjelaskan bahwa pandangan karyawan ketika mereka telah diperlakukan dengan baik oleh organisasi, mereka akan cenderung untuk bersikap dan berperilaku lebih produktif terhadap organisasi. Sama halnya ketika karyawan telah nyaman berada didalam suatu organisasi, mereka merasa bahwa adanya hubungan batin antara dirinya dan organisasi. Sehingga segala sesuatu yang dilakukannya semata hanya untuk kepentingan organisasi. Semakin tinggi tingkat komitmen karyawan maka semakin tinggi tingkat produktif karyawan selama bekerja yang menyebabkan meningkatnya kinerja karyawan. Hasil penelitian Tumigolung et. al. (2019); Rosyidah et. al. (2019); Joko et. al. (2019); Widodo et. al. (2019) menunjukkan bahwa komitmen organisasi berpengaruh terhadap kinerja karyawan.

H2: Diduga komitmen organisasi berpengaruh terhadap kinerja karyawan.

\subsection{Organizational Citizenship Behavior memoderasi Pengaruh Budaya Organisasional Terhadap Kinerja Karyawan}

Budaya organisasi merupakan kebiasaan berperilaku dalam organisasi yang diikuti oleh para anggota organisasi. Budaya yang dapat menjadikan organisasi menjadi lebih kuat dalam mencapai tujuanya merupakan budaya yang produktif (Rosyidah et. al., 2018). Organizational citizenship behavior merupakan perilaku karyawan yang bekeja diluar job desk tetapi memberikan keuntungan pada perusahaan atau dengan kata lain perilaku sukarela karyawan yang membantu produktivitas organisasi. Harapan perusahaan karyawan harus mampu melakukan tugas yang diberikan walaupun bukan tugas utama, dimana karyawan akan memperoleh feedback apabila mampu memberikan kontribusi positif bagi perusahaan. (Putra et. al., 2018).

Karyawan yang berperilaku OCB bekerja berlandaskan budaya organisasi diharapkan 
mampu memberikan yang terbaik dan kepuasan kerja karena merasa nyaman dimana karyawan tersebut bekerja. Dengan Kepuasan kerja yang didapatkan oleh karyawan, organisasi berharap untuk berperilaku positif sehingga membantu produktifitas perusahaan (Putra et. al., 2018). Sejalan dengan Mahardika dan Wibawa (2019) bahwa budaya organisasi mampu memberikan dampak positif bagi OCB disuatu perusahaan. Semakin positif pegawai dalam menilai budaya organisasi dan semakin terlibat ia dalam organisasi yang ada di instansinya, maka kecenderungan OCB akan meningkat pula.

Organizational citizenship behavior berdasarkan teori pertukaran sosial Fung et. al. (2012) yaitu ketika karyawan patuh kepada aturan atau prosedur dalam bekerja, makaakan menciptakan dampak positif yaitu munculnya perilaku. Perilaku ini menunjukkan tindakan karyawan dalam melakukan pekerjaan di luar tanggungjawabnya. Karyawan memberikan toleransi terhadap ketidaknyamanan dalam bekerja apabila terdapat aturan yang kurang efektif. Sehingga OCB dapat memberikan nilai tambah karyawan dengan memberikan kontribusi efektif dan efisien bagi organisasi. Hal ini sejalan dengan hasil studi Nurcahyo (2018) bahwa organizational citizenship behaviormemoderasi pengaruh budaya organisasi terhadap kinerja karyawan.

H3: Diduga organizational citizenship behavior memoderasi pengaruh budaya organisasional terhadap kinerja karyawan.

\subsection{Organizational Citizenship Behavior \\ Memoderasi Pengaruh Komitmen \\ Organisasional Terhadap Kinerja \\ Karyawan}

Komitmen organisasi yang tinggi dimiliki karyawan akan melakukan tidak hanya melaksanakan tugas pokoknya tetapi dengan sukarela akan mengerjakan hal-hal yang dapat digolongkan sebagai usaha-usaha ekstra (extra effort) (Mahardika dan Wibawa, 2019). Menurut Kurniawan et. al. (2019) kinerja karyawan merupakan hal yang sangat penting dalam upaya perusahaan untuk mencapai tujuannya. Dimana akan mendorong peningkatan efisiensi, efektivitas, atau kualitas yang lebih tinggi dari penyelesaian serangkaian tugas yang dibebankan kepada seorang karyawan dalam suatu organisasi atau perusahaan. Oleh karena itu, karyawan yang memiliki komitmen organisasi yang tinggi akan selalu berkontribusi terhadap karyawan dengan maksimal.

Berkaitan dengan kinerja karyawan dalam organisasi OCB tidak hanya mencakup in-role atau bekerja sesuai dengan job description saja tetapi juga extra-role yang memberikan kontribusi lebih bagi organisasi. Dengan komitmen organisasi yang baik akan berdampak bagi karyawan untuk loyal terhadap organisasi. Oleh sebab itu organisasi yang memiliki komitmen terhadap karyawan disupport dengan karyawan yang loyal terhadap organisasi ini tetu memberikan kenyaman bagi karyawan sehingga meningkatkan kinerja (Pandey et. al., 2019).

Organizational citizenship behavior menurut teori pertukaran sosial menurut Fung et. al. (2012) yaitu ketika karyawan merasa puas dengan pekerjaannya, maka karyawan tersebut merasa telah menjadi bagian (sense of belonging) dari organisasi yang menyebabkan perilaku seperti organizational citizenship behavior. OCB dapat memperkuat komitmen karyawan kepada perusahaan yaitu bagaimana sifat dan tingkah laku karyawan tersebut selama berada dalam perusahaan. Salah satunya adalah timbulnya perasaan dari karyawan yaitu dengan berusaha melebihi yang diharapkan organisasi. Hal ini sejalan dengan hasil studi Nurcahyo (2018), Srimulyani et. al. (2017), Kurniawan dan Wahyudi (2015) bahwa organizational citizenship behavior memoderasi pengaruh komitmen organisasi terhadap kinerja karyawan.

H4: Diduga organizational citizenship behaviormemoderasi pengaruh komitmen organisasional terhadap kinerja karyawan.

\section{Metode Penelitian}

Penelitian merupakan jenis penelitian kausalitas. Menurut Sugiyono (2014) desain kausalitas dapat menganalisis bagaimana suatu variabel mempengaruhi variabel lainnya, yaitu melihat pengaruh variabel independen terhadap variabel dependen secara langsung. Peneliti menggunakan desain penelitian ini untuk memberikan bukti empiris dan menganalisis budaya organisasi dan komitmen organisasi sebagai variabel independen, 
organizational citizenship behavior (OCB) sebagai variabel moderasi dan kinerja karyawan daerah sebagai variabel dependen. Model penelitiannya dapat dilihat pada gambar 1 berikut ini:

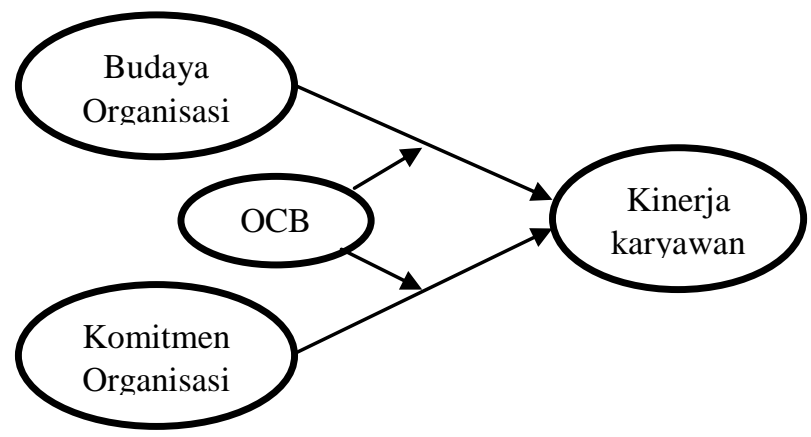

Gambar 1: Model Penelitian

Teknik pengumpulan data yang digunakan dalam penelitian ini adalah survei, dengan penyebaran kuesioner langsung kepada responden yaitu seluruh karyawan tenaga alihdaya SKK Migas Sumbagut. Kuesioner dirancang dengan menggunakan skala linkert, variabel budaya organisasi mengadopsi Andini (2018) dengan indikator (1) inovasi dan pengambilan risiko; (2) perhatian ke rincian; (3) orientasi hasil; (4) orientasi individu; (5) orientasi tim; (6) agresivitas, dan (7) Stabilitas. Komitmen organisasi diukur dengan indikator (1) komitmen afektif: (2) komitmen berkelanjutan; dan (3) komitmen normatif (Mulyajansih, 2019). Selanjutnya variabel organizational citizenship behavior diukur dengan indikator (1) Altruism; (2) civic virtue; (3) consencientiousness; (4) courtesy (Andini, 2018). Variabel kinerja karyawan diukur dengan indikator (1) sportmanship quality; (2) quantity; (3) timeliness; (3) cost effectiveness; (4) need for supervision; dan (5) interpersonal impact (Andini, 2018). Selanjutnya pengambilan kembali kuesioner disesuaikan dengan waktu yang telah disepakati oleh peneliti dengan yang bersangkutan. Adapun tahapan analisis data yang dilakukan terdiri dari statistik deskriptif, uji kualitas data, uji asumsi klasik, dan uji hipotesis.

\section{Hasil Penelitian dan Pembahasan}

\subsection{Gambaran Umum Objek Penelitian}

Kuesioner yang disebarkan dalam penelitian ini adalah sebanyak 44 kuesioner kepada sampel yang terpilih dapat dilihat dalam tabel 2 berikut:

Tabel 2. Jumlah Kuesioner

\begin{tabular}{lcc}
\hline \multicolumn{1}{c}{ Penyebaran Kuesioner } & Total & $\%$ \\
\hline Kuesioner dibagikan & 44 & $100 \%$ \\
Kuesioner yang tidak kembali & 6 & $13,64 \%$ \\
Kuesioner kembali & 38 & $86,36 \%$ \\
Kuesioner tidak lengkap & - & $0 \%$ \\
Kuesioner yang dapat digunakan & 38 & $86,36 \%$ \\
\hline
\end{tabular}

Dari tabel 2 di atas menunjukkan bahwa jumlah kuesioner yang kembali adalah sebanyak 38 atau 86,36\%. Kuesioner yang tidak kembali adalah sebanyak 6 atau 13,64\%. Hal ini dikarenakan kesibukan responden dan waktu penyebaran yang kurang tepat sehingga responden tidak sempat mengisi sampai waktu pengembalian. Seluruh kuesioner yang kembali seluruhnya bisa terpakai. Jadi, kuesioner yang memenuhi persyaratan serta layak untuk dipakai dalam penelitian ini adalah 38 kuesioner dengan tingkat persentase $86.36 \%$.

Tabel 3. Demograsi responden

\begin{tabular}{|c|c|c|}
\hline Karakteristik & Frekuensi & $\%$ \\
\hline \multicolumn{3}{|l|}{ Jenis Kelamin } \\
\hline - Laki-laki & 24 & $63,16 \%$ \\
\hline - Perempuan & 14 & $36,84 \%$ \\
\hline \multicolumn{3}{|l|}{ Kelompok Umur } \\
\hline - $<20$ tahun & 1 & $2,63 \%$ \\
\hline - 21-39 tahun & 26 & $78,42 \%$ \\
\hline - $\quad>40$ tahun & 11 & $28,95 \%$ \\
\hline \multicolumn{3}{|l|}{ Masa kerja } \\
\hline - $\quad<1$ tahun & 9 & $23.68 \%$ \\
\hline - 2-5 tahun & 12 & $31.58 \%$ \\
\hline - 6-9 tahun & 9 & $23.68 \%$ \\
\hline - $\quad>10$ tahun & 8 & $21.06 \%$ \\
\hline \multicolumn{3}{|l|}{ Pendidikan } \\
\hline - SMA sederajat & 12 & $31,58 \%$ \\
\hline - Diploma & 2 & $5,26 \%$ \\
\hline - $\quad$ Sarjana & 24 & $63,16 \%$ \\
\hline
\end{tabular}

\subsection{Uji Statistik Deskriptif}

Gambaran mengenai variabel-variabel penelitian yaitu partisipasi anggaran, gaya kepemimpinan, goal komitmen, sasaran anggaran, kinerja manajerial dapat disajikan dalam tabel descriptive statistic yang menunjukkan angka minimum, maksimum, mean dan standar deviasi yang dapat dilihat pada tabel 4 di bawah ini: 
Tabel 4. Uji Statistik Deskriptif

\begin{tabular}{lccccc}
\hline & N & Min & Max & Mean & Std. Dev \\
\hline $\begin{array}{l}\text { Kinerja } \\
\text { karyawan }\end{array}$ & 38 & 65 & 90 & 76.24 & 6.602 \\
$\begin{array}{l}\text { Budaya } \\
\text { organisasi }\end{array}$ & 38 & 76 & 109 & 9.50 & 7.120 \\
$\begin{array}{l}\text { Komitmen } \\
\text { organisasi }\end{array}$ & 38 & 26 & 58 & 44.32 & 6.050 \\
$\begin{array}{l}\text { OCB } \\
\begin{array}{l}\text { Valid N } \\
\text { (listwise) }\end{array}\end{array}$ & 38 & 49 & 70 & 58.68 & 5.836 \\
\hline
\end{tabular}

Sumber: Data Olahan (2020)

\subsection{Uji Kualitas Data}

Dari data olahan dapat diketahui masingmasing item pernyataan valid, hal ini dapat diidentifikasi berdasarkan, apabila nilai korelasi besar dari $r$ tabel maka data tersebut valid. Data diatas menunjukkan nilai korelasi lebih besar dari $\mathrm{r}$ tabel, nilai $\mathrm{r}$ tabel yaitu degree of freedom $(\mathrm{df})=\mathrm{n}-2=38-2=36$ dengan alpha 0,05 didapat $r$ tabel 0,2006. Dengan demikian item pernyataan yang digunakan dinyatakan valid dan bisa digunakan. Uji reliabilitas digunakan untuk melihat apakah hasil yang diperoleh melalui instrument tersebut konsisten dan dapat dipercaya. Adapun hasil uji reliabilitas yang diperoleh dari dalam penelitian dapat dilihat dari nilai cronbach alpha besar dari 0,60. Reliabilitas kurang dari 0,60 adalah kurang baik, sedangkan 0,60 keatas dapat diterima. Hal ini menunjukkan bahwa indikator setiap variabel dapat dikatakan reliabel.

\subsection{Uji Asumsi Klasik}

Uji normalitas menggunakankolmogrovsmirnov test diperoleh nilai Asymp. Sig 0,200 lebih besar dari 0,05, maka disimpulkan bahwa data berdistribusi normal dan ini memenuhi syarat untuk melkukan uji regresi berganda. Selanjutnya uji multikolinearitas bertujuan untuk menguji apakah dalam suatu model regresi ditemukan adanya korelasi antara variabel independen atau tidak. Uji multikolinearitas ini dengan melihat nilai variance inflation factor (VIF) dan tolerance value (nilai toleransi). Berdasarkan uji statistis diperoleh nilai tolerance tidak ada yang lebih kecil dari 0,10 dan VIF menunjukkan nilai yang lebih jauh kecil dari 10. Jadi, dapat disimpulkan bahwa tidak terdapat multikolinearitas antara variabel independen dalam model regresi. Uji heteroskedastisitas dimaksudkan untuk mengetahui apakah variasi residual absolut sama atau tidak untuk semua pengamatan. Adapun uji heteroskedastisitas dilakukan dengan menggunakan uji glejser menunjukkan nilai signifikansi tidak ada yang lebih kecil dari 0,05. Jadi, dapat disimpulkan bahwa tidak terdapat masalah heteroskedastisitas antara variabel independen dalam model regresi.

\subsection{Koefisien Determinasi $\left(R^{2}\right)$}

Tabel 5. Uji Koefisien Determinasi

\begin{tabular}{ccccc}
\hline Model & $\mathrm{R}$ & $\begin{array}{c}\mathrm{R} \\
\text { Square }\end{array}$ & $\begin{array}{c}\text { Adjusted } \\
\text { R Square }\end{array}$ & $\begin{array}{c}\text { Std. Error of the } \\
\text { Estimate }\end{array}$ \\
\hline 1 &, $803^{\mathrm{a}}$ &, 646 &, 577 &, 0221
\end{tabular}

Sumber: Data Primer yang diolah (2020)

Berdasarkan tabel 5 di atas nilai Adjusted $R^{2}$ sebesar 0,577 ini menunjukkan $57,7 \%$ budaya organisasi, komitmen manajemen, dan organizational citizenship behavior mempengaruhi kinerja karyawan. Sementara $46,3 \%$ dipengaruhi oleh faktor lain di luar model penelitian ini.

\subsection{Uji Hipotesis}

Berdasarkan uji regresi linear berganda dapat diperoleh nilai regresi pada tabel 6 sebagai berikut:

Tabel 6. Uji Regresi Berganda

\begin{tabular}{|c|c|c|c|c|}
\hline \multirow[t]{2}{*}{ Model } & \multicolumn{2}{|c|}{$\begin{array}{l}\text { Unstandardized } \\
\text { Coefficients }\end{array}$} & \multirow[t]{2}{*}{$\mathrm{T}$} & \multirow[t]{2}{*}{ Sig. } \\
\hline & B & Std. Error & & \\
\hline (Constant) & 9.395 & 10.445 & .899 & .375 \\
\hline $\begin{array}{l}\text { Budaya } \\
\text { organisasi }\end{array}$ & .635 & .135 & 4,714 & $.000 *$ \\
\hline $\begin{array}{l}\text { Komitmen } \\
\text { organisasi }\end{array}$ & -.339 & .141 & -2.829 & $.008 *$ \\
\hline $\begin{array}{l}\text { Budaya } \\
\text { organisasi*OCB }\end{array}$ & -1.156 & 1.122 & -1.030 & .311 \\
\hline $\begin{array}{l}\text { Komitmen } \\
\text { organisasi*OCB }\end{array}$ & -1.755 & 1.039 & -1.689 & .312 \\
\hline
\end{tabular}

Sumber: Data Primer yang diolah (2020)

\subsection{Pembahasan}

\section{Pengaruh Budaya Organisasional Terhadap Kinerja Karyawan}

Berdasarkan hasil pengujian hipotesis telah membuktikan bahwa budaya organisasi berpengaruh positif dan signifikan terhadap kinerja karyawan SKK Migas. Dalam penelitian ini, SKK Migas Sumbagut mengalami masalah kesenjangan antara karyawan tetap, dan karyawan tidak tetap, terhadap tenaga alih daya dari sisi 
tanggungjawab dan gajinya. Hal ini menyebabkan adanya pengaruh dari kinerja karyawan yaitu menurunnya produktivitas kinerja karyawan. Budaya organisasi yang diterapkan oleh SKK Migas Sumbagut adalah memberdayakan TAD untuk bisa dalam mengerjakan berbagai macam job desk walaupun itu bukan menjadi tugas inti mereka. Ini menyebabkan load pekerjaan yang melebihi seharusnya, sehingga mereka tidak terlalu fokus mengerjakan tugas dan tanggungjawab yang menyebabkan menurunnya produktivitas kinerja.

Menurut teori pertukaran sosial, bahwa apabila budaya yang diterapkan perusahaan dapat dijalankan dengan baik, maka terdapat keseimbangan antara seluruh karyawan baik dari segi tanggungjawab dan gaji. Budaya organisasi merupakan sebuah pedoman bagi perusahaan dimana sebuha organisasi akan berjalan dengan baik apabila menerapkan budaya organisasi yang baik dimana normanorma dan nilai-nilai yang diterapkan guna kepentingan dan aturan dari perusahaan berguna demi kinerja karyawan. Sehingga, adanya budaya organisasi, pegawai akan berusaha untuk bertanggung jawab terhadap tugas pekerjaan yang diberikan organisasi dengan menunjukkan rasa integritas. Rasa integritas ini akan berdampak terhadap kinerja pegawai. Hal ini sejalan dengan studi Tumigolung et. al. (2019) dan Rosyidah et. al. (2019) bahwa terdapat pengaruh antara budaya organisasional terhadap kinerja karyawan.

\section{Pengaruh Komitmen Organisasional Terhadap Kinerja Karyawan}

Berdasarkan hasil pengujian hipotesis ditemukan bahwa komitmen organisasi berpengaruh negatif terhadap kinerja karyawan dikarenakan rendahnya komitmen organisasional karyawan akibat kesenjangan jabatan yang diberikan terutama masalah gaji yang tidak sesuai dengan tanggung jawab karyawanya. Dimana adanya keyakinan karyawan terhadap organisasi akan menimbulkan masalah pada hubungan emosional antara karyawan dengan perusahaan. Sehingga apapun yang dilakukannya semata-mata hanya untuk kepentingan dirinya sendiri, bukan untuk kepentingan perusahaan. Hal ini sejalan dengan pernyataan Joko et. al. (2019) bahwa komitmen pegawai merupakan salah satu kunci yang turut menentukan berhasil tidaknya suatu organisasi untuk mencapai tujuannya. Pegawai yang mempunyai komitmen pada organisasi biasanya mereka menunjukan sikap kerja yang penuh perhatian terhadap tugasnya, mereka sangat memiliki tanggung jawab untuk melaksanakan tugas-tugas serta sangat loyal terhadap organisasi. Seperti dalam penelitian ini, produktivitas minyak bumi dan gas alam mengalami kenaikan dan penurunan tiap tahunnya. Hal ini dikarenakan komitmen organisasional dalam diri karyawan yang tidak konsisten akibat kesenjangan antara karyawan. Sehingga berpengaruh terhadap kinerja karyawan.

\section{Organization Citizenship Behavior tidak Memoderasi Pengaruh Budaya Organisasional Terhadap Kinerja Karyawan}

Berdasarkan hasil pengujian hipotesis menunjukkan bahwa Budaya organisasional yang dimoderasi organization citizenship behavior tidak berpengaruh terhadap kinerja karyawan dikarenakan OCB tidak akan muncul apabila perusahaan itu sendiri tidak menerapkan budaya organisasi atau tidak berjalan dengan baik. Dengan diterapkannya budaya organisasional di SKK Migas Perwakilan Sumbagut yaitu para TAD banyak melakukan pekerjaan diluar jobdesk tanpa adanya insentif atau penghargaan lainnya, walaupun ini dinilai positif oleh para Manajemen tetapi hal ini juga menjadi pemicu menurunnya produktivitas kinerja karena load pekerjaan yang terlalu banyak. Dengan adanya budaya seperti, menyebabkan TAD pun enggan melakukan inisiatif-inisiatif yang akan menambah beban kerja mereka. Sejalan dengan Nurcahyo (2018) bahwa budaya organisasi yang sudah ada di dalam suatu organisasi apabila ditunjang dengan aparatur atau karyawan yang senantiasa melaksanakan budaya tersebut, maka akan memberikan hasil yang baik untuk meningkatkan kinerja. Kinerja karyawan sangat didukung dengan budaya organisasi yang diterapkan dalam suatu organisasi.Namun dalam penelitian ini sebagian karyawan mengalami penurunan kinerja akibat kesenjangan sosial yang mengakibatkan ketidakpatuhan karyawan. Sehingga adanya perilaku organizational 
citizenship behavior tidak akan mempengaruhi kinerja karyawan apabila budaya didalam perusahaan tidak berjalan sebagaimana mestinya.

\section{Organization Citizenship Behavior tidak Memoderasi Pengaruh Komitmen Organisasional Terhadap Kinerja Karyawan}

Berdasarkan hasil pengujian hipotesis ditemukan bahwa komitmen organisasional yang dimoderasi organization citizenship behavior tidak berpengaruh terhadap kinerja karyawan dikarenakan komitmen yang tinggi dan konsisten dari karyawan belum tentu akan bertanggungjawab penuh terhadap pekerjaannya. Selain itu adanya isu terkait perbedaan tanggung jawab dan insentif membuat karyawan menjadi kecewa terhadap perusahaan. Meskipun organization citizenship behavior merupakan sifat yang mampu meningkatkan kinerja. Namun hal ini tidak mempengaruhi komitmen organisasional sehingga tidak ada hubungan antara OCB terhadap kinerja karyawan. Pada SKK Migas Perwakilan Sumbagut, TAD merasa mereka bukan sepenuhnya bagian dari SKK Migas karena mereka berkontrak atau dikelola oleh Jasa Pengelolaan Tenaga Alih Daya, ini mengakibatkan enggan melakukan perilaku OCB. Sejalan dengan pernyataan Maghfironsyah dan Yuniawan (2019) ketika seseorang memiliki komitmen yang kuat terhadap organisasinya, orang tersebut akan berusaha semaksimal mungkin memberikan yang terbaik agar dapat bertahan di dalam organisasinya dan juga akan berdampak baik bagi organisasinya, dan tingkat loyalitas anggotanya akan secara otomatis terbentuk dan cenderung tinggi. Begitu juga sebaliknya, jika seseorang memiliki komitmen yang dianggap atau dirasa kurang, maka tingkat loyalitasnya juga akan ikut kurang bahkan cenderung rendah.

\section{Kesimpulan}

Berdasarkan pembahasanan yang telah dipaparkan sebelumnya, penulis memperoleh kesimpulan bahwa budaya organinisasi berpengaruh positif signifikan terhadap kinerja karyawan. Hal ini menujukan bahwa dengan budaya organisasi yang baik akan mengakibatkan kinerja karyawan lebih baik. Selanjutnya komitmen organisasi berpengaruh negatif signifikan terhadap kinerja karyawan. Hal ini menunjukkan bahwa apabila seorang karyawan yang memiliki komitmen justru menurunkan kinerja. Ini dikarenakan yang respondennya adalah karyawan dengan status alih daya dimana kompensasi yang mereka terima tidak sesuai dengan beban kerja yang mereka dapat, disamping itu dalam jangka panjang status mereka juga tidak jelas. Disamping itu organizational citizenship behavior tidak memoderasi pengaruh budaya organisasi dan komitmen organisasi terhadap kinerja karyawan. Ini disebabkan tenaga alih daya merupakan karyawan kontrak, dimana tenaga mereka hanya dipakai ketika perusahaan memiliki kontrak kerjasama.

Keterbatasan penelitian ini hanya mengangkat variabel komitmen organisasi dan budaya organisasi serta menggunakan sampel penelitian tenaga adidaya SKK Migas Sumbagut. Untuk penelitian selanjutnya saran yang diberikan adalah dapat menambah faktor lain seperti karakter personal dan lain-lain. Selanjutnya penelitian dapat dilakukan pada objek yang lebih luas, tidak hanya pada SKK Migas Sumbagut.

Implikasi hasil penelitian ini dapat dikemukakan implikasi secara teoritis dan praktis. Secara teoritis dapat menambah literatur penelitian tentang kinerja karyawan. Sedangkan secara praktis hasil penelitian ini dapat dijadikan bahan evaluasi bagi SKK Migas untuk mempertimbangkan kesejahteraan lebih pada tenaga alih daya karena tenaga mereka dimanfaatkan hanya jangka pendek. Disamping itu diberikan kesempatan menjadi karyawan tetap atau tidak tetap bagi mereka yang memiliki loyalitas yang tinggi perusahaan.

\section{Daftar Pustaka}

Aprianti, D. I., dan Bhaihaki, M. (2017). Pengaruh Organizational Citizenship Behavior (OCB) Terhadap Kinerja Pada Karyawan PT. Bank Central Asia Kantor Cabang Utama Samarinda. Jurnal Ekonomika, Vol.2 No.2 Hal: 97-110.

Akbar, A., Musadieq, M.A., dan Mukzam, M.D. (2017). Pengaruh Komitmen Organisasional Terhadap Kinerja (Studi 
Pada Karyawan PT. Pelindo Surabaya). Jurnal Administrasi Bisnis (JAB), Vol. 47 No.2 Hal: 33-38.

Claresta, A.D. (2019). Pengaruh Employee Engagement dan Budaya Organisasi Terhadap Organizational Citizenship Behavior (OCB) (Studi Pada Perawat dan Bidan Rumah Sakit Permata Bunda Malang). Jurnal Ilmiah Mahasiswa FEB Universitas Brawijaya, Vol. 8 No.1 Hal: 117.

Defrionaldo dan Rivai, A.H. (2019). Pengaruh Dukungan Organisasi dan Persepsi Keadilan Organisasional Terhadap Kinerja Karyawan Dengan Organizational Citizenship Behavior Sebagai Variabel Mediasi: Studi Pada Karyawan Beacukai Pekanbaru. Jurnal Ilmiah Mahasiswa Ekonomi Manajemen, Vol. 4 No.3 Hal: 544-561.

Dewi, A. R. S., dan Hasniaty. (2017). Pengaruh Gaya Kepemimpinan, Budaya Organisasi dan Komitmen Organisasi Terhadap Kinerja Pegawai Dinas Pertanian Kabupaten Mamuju. Jurnal Bisnis, Manajemen dan Informatika, Vol. 14 No.2 Hal: 92-102.

Fung, N. S., Ahmad, A., dan Omar, Z. (2012). Work-Family Enrichment: It's Mediating Role in The Relationship between Dispositional Factors and Job Satisfaction. International Journal of Academic Research in Business and Social Science. Vol. 2 No.11 Hal: 11-88.

Ghozali, I. (2016). Aplikasi Analisis Multivariete Dengan Program IBM SPSS 23 (Edisi 8). Cetakan ke VIII. Semarang: Badan Penerbit Universitas Diponegoro.

Halim, A. N., dan Dewi M. B. (2018). Analisa Pengaruh Organizational Citizenship Behavior Terhadap Kinerja Karyawan Hotel Bintang 3 di Surabaya. Journal Hospitaly dan Manajemen Jasa, Vol. 6 No.2 Hal: 183-196.

Herdiany, H. D. (2015). Pengaruh Budaya Organisasi, Motivasi, dan Kepuasan Kerja Terhadap Kinerja Karyawan Pada PT. Iskandar Indah Printing Textile Surakarta. Naskah Publikasi. Universitas Muhammadiyah Surakarta.

Joko, T., Munir, R., dan Fattah, N. (2019). Pengaruh Pengembangan Karir,
Pengawasan dan Komitmen Pegawai Terhadap Kinerja Pegawai di Dinas Pengendalian Penduduk dan Keluarga Berencana Kabupaten Bantaeng. Journal of Management, Vol. 2 No.2 Hal: 1-16.

Kurniawan, H. D., dan Wahyudi, A. (2015). Pengaruh Kepuasan Kerja dan Komitmen Organisasional Terhadap Kinerja Dengan Organizational Citizenship Behavior Sebagai Variabel Moderasi. Jurnal Manajemen Sumberdaya Manusia, Vol. 9 No.1 Hal: 1-10.

Kurniawan, R. A., Qomariah, N., dan Winahyu, P. (2019). Dampak Organizational Citizenship Behavior, Motivasi Kerja, dan Kepuasan Kerja Terhadap Kinerja Karyawan. Jurnal Penelitian IPTEKS, Vol.4 No.2 Hal: 148160.

Maghfironsyah, F.A., dan Yuniawan, A. (2019). Analisis Hubungan Big Five Personality dan Komitmen Organisasi Serta Pengaruhnya Terhadap Organizational Citizenship Behavior (Studi Pada Karyawan Dinas Kesehatan Kota Salatiga). Diponegoro Journal of Management, Vol. 8 No.4 Hal: 1-14.

Mahardika, I. N. B. P., dan Wibawa, I. M. A. (2019). Pengaruh Budaya Organisasi Kepuasan Kerja dan Komitmen Organisasional Terhadap Organizational Citizenship Behavior Pada Karyawan. EJurnal Manajemen, Vol. 8 No.1 Hal: 73407370.

Marsoit, P., Sendow, G., dan Rumokoy, F. (2017). Pengaruh Pelatihan, Disiplin Kerja dan Komitmen Organisasi Terhadap Kinerja Karyawan PT. Asuransi Jasa Indonesia. Jurnal EMBA, Vol. 5 No.3 Hal: 4285-4294.

Marlina, E., dan Zega, B. L, (2019). Analisis Determinasi Kinerja Manajerial: Studi Empiris Pada Rumah Sakit Umum Daerah Propinsi Riau. Muhammadiyah Riau Accounting and Business Journal, Vol 1 No 1 Hal: 1-9

Megantara, I., Suliyanto, dan Purnomo, R. (2019). Pengaruh Budaya Organisasi dan Rotasi Pekerjaan Terhadap Motivasi Kerja Untuk Meningkatkan Kinerja Pegawai. Jurnal Ekonomi, Bisnis, dan Akuntansi (JEBA), Vol. 21 No.1 Hal: 1-20. 
Nurcahyo, W. (2018). Faktor-Faktor Yang Mempengaruhi Kinerja Karyawan Dengan Organizational Citizenship Behavior Sebagai Variabel Moderating (Studi Empiris Pada SKPD Kabupaten Karanganyar). Naskah Publikasi. Universitas Muhammadiyah Surakarta.

Pandey, K. K., Lengkong, V., dan Kojo, C. (2019). Pengaruh Dukungan Organisasi, Kepuasan Kerja dan Komitmen Organisasi Terhadap Organizational Citizenship Behavior Pada Bank Sulutgo. Jurnal EMBA, Vol. 7 No.4 Hal: 5266-5275.

Putra, D. S., Susilo, H., dan Aini, E. K. (2018). Pengaruh Budaya Organisasi Terhadap Organizational Citizenship Behavior (OCB) Dengan Kepuasan Kerja Sebagai Variabel Intervening (Studi Pada Karyawan Kusuma Agrowisata Divisi Hotel Kota Batu). Jurnal Administrasi Bisnis, Vol. 62 No.2 Hal: 28-36.

Robbins, S. P., dan Judge, T. A. (2017). Perilaku Organisasi: Organizational Jakarta: Salemba Empat.

Rosyidah, E., Fadah, I., dan Tobing, D. S. K. (2018). Pengaruh Kepuasan Kerja dan Budaya Organisasi Terhadap Kinerja Pegawai Melalui Komitmen Organisasi di Unit-Unit Pelayanan Publik Kabupaten Jember. Jurnal Ekonomi (RELASI), Vol. 14 No.1 Hal: 1-16.

Setiawan, P. (2019).

https://www.gurupendidikan.co.id/5-

pengertian-teori-pertukaran-sosialmenurut-para-ahli-pengertian-teoripertukaran-sosial-menurut-para-ahli, yang diakses pada tanggal 13 Maret 2020.

Srimulyani, I., Murniningsih, R., dan Raharja, B. S. (2017). Pengaruh Komitmen Organisasional terhadap Kinerja Karyawan dengan Organizational Citizenship Behavior (OCB) sebagai Variabel Moderating. The $6^{\text {th }}$ University Research Colloquium 2017. Universitas Muhammadiyah Magelang.

Sugiyono. (2016). Metode Penelitian Kuantitatif, Kualitatif dan $R \& D$. Bandung: PT Alfabeta.

Tumigolung, R., Sepang, J., dan Hasan A. B. (2019). Pengaruh Budaya Organisasi, dan Komitmen Karyawan Terhadap Kinerja Karyawan PT. Bank Mandiri di Manado.
Jurnal EMBA, Vol. 7 No.3 Hal: 41064115 .

Widodo, A., Sunaryo, H., dan Khairul. (2019). Pengaruh Kecerdasan Emosional, Komitmen Organisasional, dan Organizational Citizenship Behavior Terhadap Kinerja Karyawan PT. Bank Muamalat Cabang Malang. E-Jurnal Riset Manajemen, Vol. 8 No.7 Hal: 47-60.

Wirawan. (2013). Kepemimpinan: Teori, Psikologi, Perilaku Organisasi, Aplikasi dan Penelitian. Jakarta: Raja Grafindo Persada. 